\title{
Research and Practice on Innovative Methods of Ideological and Political Education for College Students Based on Internet of Things + Technologies*
}

\author{
$\mathrm{Na} \mathrm{An}^{1}$ \\ Hebei Normal University of \\ Science \& Technology
}

\author{
Jing Wang ${ }^{2}$ \\ Hebei Normal University of \\ Science \& Technology
}

\author{
Honglei Wang ${ }^{3}$ \\ Hebei Normal University of \\ Science \& Technology
}

\begin{abstract}
The Internet of Things is an important trend in the development of information technology after the Internet and the mobile communication network. It attracts college students through its advanced technical means and rich contents, and has brought far-reaching influence on the ideological and political education of college students. Therefore, it is of great theoretical and practical significance to explore the application of Internet of Things in ideological and political education in colleges and universities. This paper deeply analyzes the current situation of ideological and political education of college students in China under the background of Internet of Things, and finds that the application of technologies of the Internet of Things in education is mainly embodied in three aspects: classroom teaching, extracurricular learning and educational management. The main problems of ideological and political education in colleges and universities are that the interest of college students in ideological and political courses is generally low, the connection and integration between the technologies of the Internet of Things and ideological and political education needs to be strengthened, and the quality of ideological and political teachers needs to be improved. At the same time, based on the Internet of Things + Technologies, it is proposed that college students' ideological and political education should be innovated in the aspects of service function, teaching mode, learning mode and the construction of teachers' team, which has a strong guiding role in the reform of ideological and political education in colleges and universities in China.
\end{abstract}

\section{Keywords}

Technologies of the Internet of Things • College Students' Ideological and Political Education • Innovation

\footnotetext{
* Y2018 Research subject of social science development in Hebei Province "Study on the Innovation of College Students' Ideological and Political Education in the New Era" (201804030102)

${ }^{1}$ Correspondence to: Na An (MSc), Hebei Normal University of Science \& Technology, Qinhuangdao 066004, China. Email: anna3142888@163.com

${ }^{2}$ Hebei Normal University of Science \& Technology, Qinhuangdao 066004, China. Email: sj99996@163.com

${ }^{3}$ Hebei Normal University of Science \& Technology, Qinhuangdao 066004, China. Email: zhouailing1978@ 163.com
}

Citation: An, N., Wang, J., \& Wang, H. L. (2018). Research and Practice on Innovative Methods of Ideological and Political Education for College Students Based on Internet of Things + Technologies. Educational Sciences: Theory \& Practice, 18(5), 2386-2393. http://dx.doi.org/10.12738/estp.2018.5.137 
After the Internet and mobile communication network, the Internet of Things has become an important trend in the development of information technology, greatly promoting the reform of the information industry in the world. Unlike smart phones and computers capable of connecting networks, the Internet of Things has changed the way people live in many areas (Chiswick \& Miller, 2007), and education is no exception. At present, all the college students in China were generally born after 1995, and with active thinking and strong thirst for knowledge, they are keen response to various information and trends of thought, and the independence and difference of college students' ideological activities are gradually enhanced. The Internet of Things, through its advanced technical means and rich content, attracts college students, which has exerted a profound influence on the ideological and political education of college students. Therefore, the ideological and political education of college students in China is facing many new situations, new problems and new challenges, which need to be paid attention to in all aspects of society. Strengthening the research and innovation of ideological and political education for college students under the background of Internet of Things is not only the inevitable demand of the development of the times, but also the essential direction of education reform in China (Zembylas, 2008). Although the research and application of technologies of the Internet of Things in the ideological and political education of college students in China is still in the initial stage, the profound technological revolution has gradually become the motive force of ideological and political education in colleges and universities, and is constantly promoting the development of education in China. Therefore, it is of great theoretical and practical significance to explore the application of Internet of Things in ideological and political education in colleges and universities (Mpimpas, 2011).

\section{Current Situation of Ideological and Political Education of College Students under the Technologies of the Internet of Things}

\section{Brief introduction to the Internet of Things}

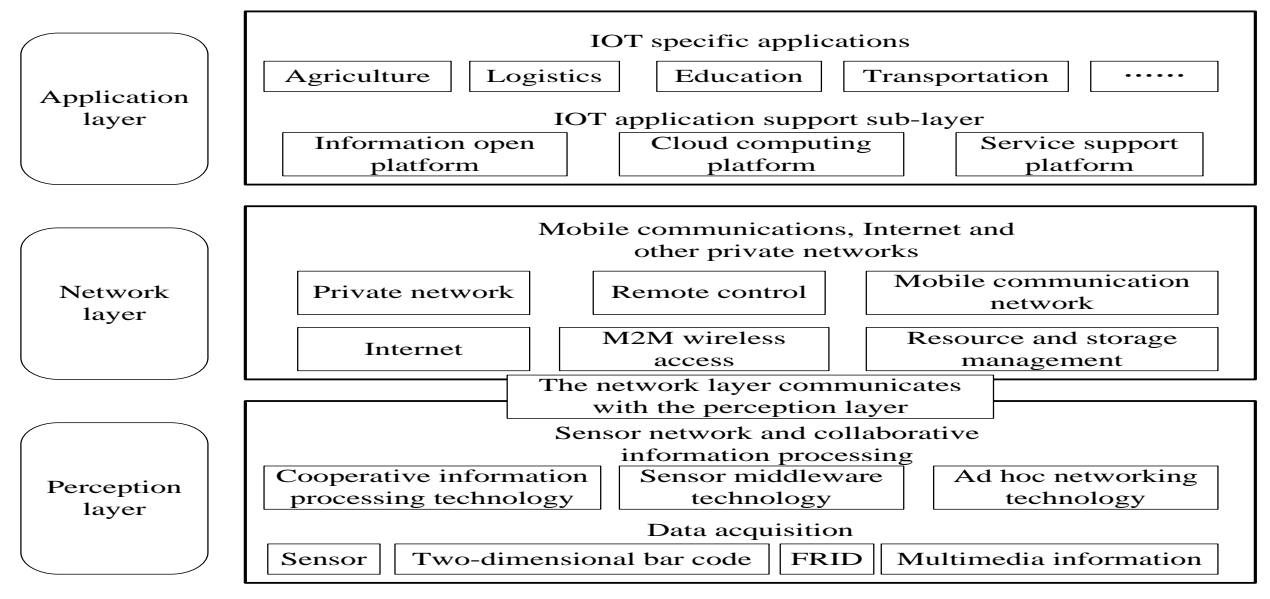

Figure 1. Three-tier architecture of the Internet of Things. 
The concept of the Internet of Things (IOT) was put forward in 1999. The Internet of Things is an important part of the new generation of information technology. The Internet of Things is an object-connected network, so the Internet of Things can be simply described as a complex system acquiring environmental physical information by a sensing network, transmitting through a communication network, and processing information through cloud computing platform (McLeish \& Nightingale, 2007). The Internet of Things can be divided into three layers: the application layer, the network layer, and the perception layer, as shown in Figure 1.

The Internet of Things mainly includes four core technologies such as RFID technology, sensor technology, intelligent technology and nanotechnology (Martins, 2011), as shown in Table 1.

Table 1

Key Technologies in the Internet of Things

Key technology Performance description

RFID technology Identifying and marking an object, similar to give an " account" to the object

Sensor Network

Technology

Smart technology Make the objects in the Internet of Things have certain intelligence

Nanotechnology

To realize the interaction and connection of small objects

At present, the application of the technologies of the Internet of Things in education is mainly embodied in classroom teaching, extracurricular learning and education management (Hoffmann, 2009), as shown in Table 2 .

Table 2

Application of the Internet of Things in Education

\begin{tabular}{|c|c|c|c|}
\hline $\begin{array}{l}\text { Application of } \\
\text { classification }\end{array}$ & Range of application & $\begin{array}{c}\text { Main } \\
\text { technology }\end{array}$ & Typical applications \\
\hline \multirow{4}{*}{$\begin{array}{l}\text { Classroom } \\
\text { teaching }\end{array}$} & The teaching evaluation & $\begin{array}{l}\text { RFID、Sensor } \\
\text { Network }\end{array}$ & $\begin{array}{l}\text { Classroom answer questions and } \\
\text { teaching feedback }\end{array}$ \\
\hline & Experimental teaching guidance & $\begin{array}{l}\text { Sensor } \\
\text { Network }\end{array}$ & The experimental operation \\
\hline & Rich teaching resources & $\begin{array}{l}\text { Sensor } \\
\text { Network }\end{array}$ & Acquisition of experimental data \\
\hline & Optimize learning environment & $\begin{array}{l}\text { Sensor } \\
\text { Network }\end{array}$ & $\begin{array}{l}\text { Classroom noise and light } \\
\text { control }\end{array}$ \\
\hline \multirow{3}{*}{$\begin{array}{l}\text { Extracurricular } \\
\text { learning }\end{array}$} & Support extracurricular research & $\begin{array}{l}\text { Sensor } \\
\text { Network }\end{array}$ & $\begin{array}{l}\text { The experimental data are sent } \\
\text { back }\end{array}$ \\
\hline & Support mobile learning & $\begin{array}{l}\text { RFID、Sensor } \\
\text { Network }\end{array}$ & $\begin{array}{l}\text { Acquisition and interaction of } \\
\text { teaching resources }\end{array}$ \\
\hline & Support ubiquitous learning & $\begin{array}{l}\text { RFID、Sensor } \\
\text { Network }\end{array}$ & $\begin{array}{l}\text { Intelligent learning service } \\
\text { implementation }\end{array}$ \\
\hline \multirow{4}{*}{$\begin{array}{l}\text { Education } \\
\text { management }\end{array}$} & Equipment management & RFID & $\begin{array}{l}\text { Teaching instruments, student } \\
\text { diploma management }\end{array}$ \\
\hline & School safety management & $\begin{array}{l}\text { RFID、Sensor } \\
\text { Network }\end{array}$ & $\begin{array}{l}\text { Dormitory safety access control, } \\
\text { school fire alarm management }\end{array}$ \\
\hline & Digital campus construction & RFID & Campus card, staff attendance \\
\hline & $\begin{array}{l}\text { Regional education } \\
\text { management informatization } \\
\text { construction }\end{array}$ & RFID & $\begin{array}{l}\text { Regional education E cartoon } \\
\text { project }\end{array}$ \\
\hline
\end{tabular}




\section{Current situation of ideological and political education for college students}

The interest of college students in ideological and political courses is generally low At present, there are many ideological and political education courses in all colleges and universities in China, but from the perspective of the response of college students, their interest in ideological and political courses is generally low. As can be seen in Figure 2, 45.2\% of college students are not interested in ideological and political courses, and only $12.5 \%$ of college students are interested in ideological and political courses.

The connection and integration of the technologies of the Internet of Things and ideological and political education should be strengthened Under the background of the Internet of Things, the teachers of ideological and political education in colleges and universities should not only have professional knowledge, but also have the ability to use technologies of the Internet of Things. In the face of this vast amount of data and information, teachers need to have a strong ability to analyze and screen, and if not using it well, it will have a negative impact on the quality of ideological and political education (Bres \& Belling, 2015). But they should not rely too much on data, which will make ideological and political education dehumanize.

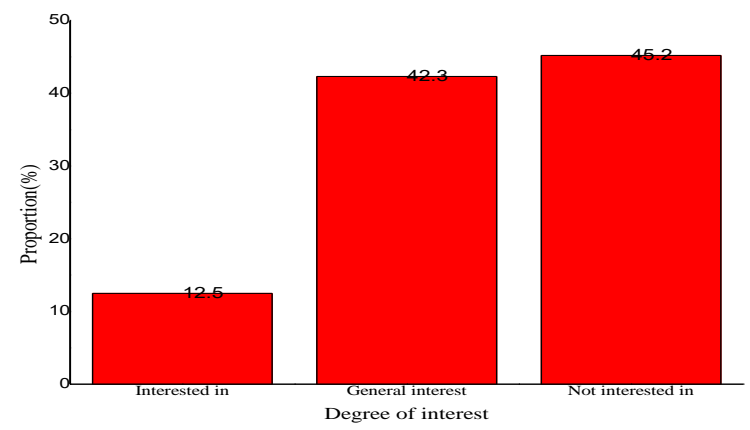

Figure 2. The degree to which college students are interested in ideological and political courses.

The quality of ideological and political teachers should be raised: The quality level of ideological and political teachers plays an important role in the quality of ideological and political education for college students. At present, college students are more and more demanding on the quality of ideological and political teachers. They require teachers not only can teach, but also need to know how to behave and handle issues (Gemenis, 2012). Figure 3 shows the quality level that college students think is lacking in ideological and political teachers.

As can be seen from Figure 3, currently, college students' expectations for ideological and political teachers include a higher level of teaching as well as rich knowledge, a model for others, caring for students, and a strong sense of responsibility. However, at present, the ideological and political teachers in colleges and universities pay more attention to teaching, and other qualities need to be strengthened and improved (Carnoy, 2002). 


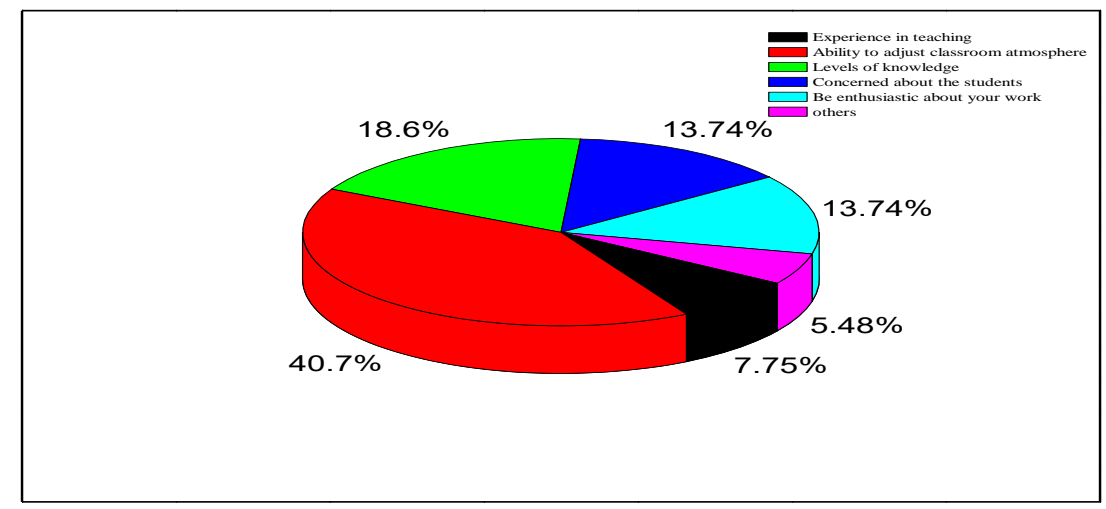

Figure 3. College students are looking at the quality of ideological and political teachers.

\section{Innovation of Ideological and Political Education under the Environment of the Internet of Things}

\section{Innovation in the service function of ideological and political education}

The traditional ideological and political education mainly has the function of guiding, education and service. With the support of the Technologies of the Internet of Things, the function of service will be more and more important in ideological and political education. First, the Internet of Things, through its technical connectivity, can be combined with any object at any time and place, enabling a humanized and one-stop service (Wolfinger \& Highton, 2005). Secondly, the Internet of Things makes use of the middleware architecture (see Figure 4), integrates various resources through intelligent regulation and management, provides diversified and characteristic ideological and political education resources, and also develop new service items and resources. In addition, the Internet of Things can store a large amount of data, provide data analysis for ideological and political education through the analysis of data, support personalized ideological and political education, and offer a variety of evaluation on learning effects, so as to achieve intelligent education.

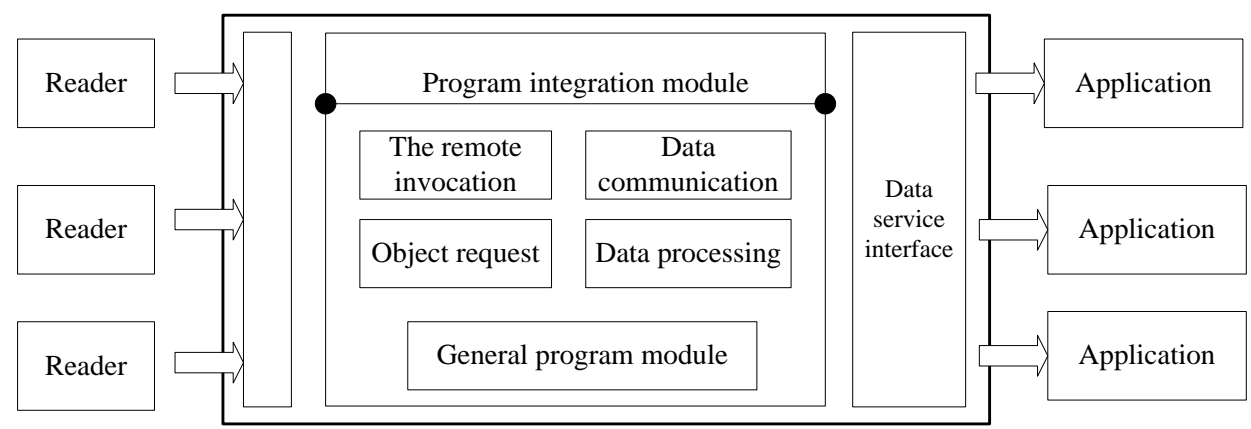

Figure 4. Middleware architecture. 


\section{Innovation of ideological and political education and teaching mode}

Compared with traditional teaching, ideological and political education under the technologies of the Internet of Things is more innovative and open in the teaching mode. Students can make full use of the powerful information resources of the Internet of Things to improve their thinking ability. At the same time, with the integrity and traceability of the Internet of Things information, students can modify or complete the study of a certain ideological and political courses at any time according to their own special interests, or choose the teaching of their favorite teachers at any time. For example, in the learning interaction model of virtual community, through the technologies of Internet of Things, students can be motivated to think deeply, summarize and extract valuable content, and share it with other students on the Internet of Things.

In addition, combining the technologies of the Internet of Things with the modern teaching concept and applying it to the scientific teaching activities can overcome some inherent obstacles in the traditional education mode and promote the cooperative education well. The Internet of Things has a large amount of data and multiview processing technology, which can stimulate students to take the initiative to carry on the desire of integration, and develop the ability of integrating and coordinating multi-subjects.

\section{Innovation of learning mode in ideological and political education}

The technologies of the Internet of Things has realized the mobile teaching, so the students have the more open learning way and can study at anytime and anywhere. Through the radio frequency identification technologies of the Internet of Things, the information transmission efficiency between teachers and students is higher, with pretty higher flexibility. Through the RFID technologies of the Internet of Things, it is possible to create a mobile ideological and political education learning environment and link personalized learning and collaborative learning effectively. At the same time, it can also promote the development of universal learning. The Internet of Things can set up intelligent ideological and political education classes through various kinds of intelligent equipment, and can carry on the scene simulation learning, so as to promote the student's all-round development. The Internet of Things can provide a supporting environment for students' regular learning, afterschool learning and regional cooperation learning, and continuously expand their learning space, which is conducive to students' autonomous learning and satisfying the needs of individualized learning.

\section{Innovation of the construction of ideological and political education teachers}

To effectively promote the development of ideological and political education for college students, it is necessary to strengthen the construction of teachers. First of all, ideological and political education teachers can skillfully use modern network technology, pay close attention to the ideological dynamics of college students, and set up right ideas for college students. Secondly, the ideological and political education teachers should actively guide and educate the students, set a model for students, and establish an atmosphere of learning from the model. In addition, colleges and universities should constantly improve the selection and training 
An, Wang, Wang / Research and Practice on Innovative Methods of Ideological and Political Education for College...

$\overline{\text { mechanism of ideological and political education teachers, develop resources through various channels, and }}$ highlight the pertinence and effectiveness of ideological and political education.

\section{Conclusions}

Based on the Internet of Things + Technologies, this paper studies the innovative methods of ideological and political education for college students, and the results show that:

The Internet of Things includes four core technologies, such as RFID technology, sensor technology, intelligent technology and nanotechnology. Their application in the field of education is mainly embodied in three aspects: classroom teaching, extracurricular learning and educational management.

The investigation shows that there are some problems in ideological and political education in colleges and universities in China, such as low interest of college students in ideological and political education, poor connection and integration between technologies of the Internet of Things and ideological and political education, and poor quality of ideological and political teachers, which need to be improved.

Based on the Internet of Things + Technologies, this paper proposes that college students' ideological and political education should be innovated in four aspects: service function, teaching mode, learning mode and teachers' building, which has a strong guiding effect on the reform of ideological and political education in colleges and universities in China.

\section{References}

Bres, J. D., \& Belling, L. (2015). Free your stuff Luxembourg! language policies, practices and ideologies in a multilingual Facebook group. Language Policy, 14(4), 1-19. http://dx.doi. org/10.1007/s10993-014-9341-z

Chiswick, B. R., \& Miller, P. W. (2007). Computer skills, destination language proficiency and the earnings of natives and immigrants. Review of Economics of the Household, 5(2), 129-157. http://dx.doi. org/10.1007/s11150-007-9007-0

Carnoy, M. D. (2002). What does globalization mean for educational change? A comparative approach. guest editorial essay. Comparative Education Review, 46(1), 1-9. http://dx.doi. org/10.1086/324053

Gemenis, K. (2012). Proxy documents as a source of measurement error in the comparative manifestos project. Electoral Studies, 31(3), 594-604. http://dx.doi. org/10.1016/j.electstud.2012.01.002

Hoffmann, B. (2009). Charismatic authority and leadership change: Lessons from Cuba's post-fidel succession. International Political Science Review, 30(3), 229-248. http://dx.doi. org/10.1177/0192512109105635

Mpimpas, H. (2011). Global activism and nationally driven recycling: the influence of world society and national contexts on public and private environmental behavior. International Sociology, 26(3), 315-345. http://dx.doi. org/10.1177/0268580910392258 
An, Wang, Wang / Research and Practice on Innovative Methods of Ideological and Political Education for College...

Mcleish, C., \& Nightingale, P. (2007). Biosecurity, bioterrorism and the governance of science: The increasing convergence of science and security policy. Research Policy, 36(10), 1635-1654. http://dx.doi. org/10.1016/j.respol.2007.10.003

Martins, C. (2011). The dangers of the single story: 1 child-soldiers in literary fiction and film. Childhood, 18(4), 434-446. http://dx.doi. org/10.1177/0907568211400102

Wolfinger, R. E., \& Highton, B. (2005). How postregistration laws affect the turnout of citizens registered to vote. State Politics \& Policy Quarterly, 5(1), 1-23. http://dx.doi. org/10.1177/153244000500500101

Zembylas, M. (2008). Engaging with issues of cultural diversity and discrimination through critical emotional reflexivity in online learning. Adult Education Quarterly, 59(1), 61-82. http://dx.doi. org/10.1177/0741713608325171 